\title{
Forest regeneration in changing environments
}

\author{
Robert G. Wagner ${ }^{1}$. Carlos A. Gonzalez-Benecke ${ }^{2}$. Andrew S. Nelson ${ }^{3}$. \\ Douglass F. Jacobs ${ }^{1}$
}

Published online: 17 October 2018

(c) Springer Nature B.V. 2018

\section{Introduction}

Successfully regenerating young forests following harvesting or natural disturbances is the first principle of sustainable forest management. Whether regeneration practices are successful or not can have substantial long-term effects on future stand dynamics, management options, and whether overall goals are achieved. Continuously adapting forest regeneration practices to changing societal needs, human and natural disturbances, policies, markets, technologies and climate, presents recurring challenges and opportunities to successfully managing forests around the globe. Therefore, testing new methods for regenerating forests is vital for meeting current and future forest management goals and ensuring the overall sustainability of forests.

Advancing the science and practice of forest regeneration and early stand management requires a regular exchange of information about new concepts, scientific methodologies, and technologies among forest researchers and managers. From July 11-13, 2017 an international conference entitled Forest Regeneration in Changing Environments was held at Oregon State University in Corvallis, OR, USA. The goal of the conference was to bring forest researchers and practitioners together to share the latest research findings related to forest regeneration and early stand dynamics in changing environments around the globe. Nearly 90 registered participants from more than 25 countries made over 70 scientific presentations. A proceedings from the conference (Wagner et al. 2017) with abstracts from all presentations was provided at the meeting and is available at: https://www.iufro.org/downl oad/file/27365/1434/10104-20115-corvallis17-abstracts_pdf/. The conference was jointly sponsored and organized by Oregon State University's College of Forestry, Purdue University's Department of Forestry and Natural Resources, and the University of Idaho's Department of Forest, Rangeland and Fire Sciences.

Douglass F. Jacobs

djacobs@purdue.edu

1 Department of Forestry and Natural Resources, Purdue University, West Lafayette, IN, USA

2 Department of Forest Engineering, Resources and Management, Oregon State University, Corvallis, OR, USA

3 Department of Forest, Rangeland and Fire Sciences, University of Idaho, Moscow, ID, USA 


\section{History of conference}

This is the ninth time that this conference has been held since 1992. Previously called the International Forest Vegetation Management Conference under IUFRO Unit 1.01.04, this meeting has occurred about every 3 years. Previous conferences were held in Halmstad, Sweden (August 2014), Valdivia, Chile (November 2011), Rotorua, New Zealand (March 2009), Corvallis, Oregon (June 2005), Nancy, France (June 2002), Sault Ste. Marie, Ontario, Canada (August 1998), Rotorua, New Zealand (March 1995), and Auburn, Alabama (April 1992).

At the Halmstad, Sweden conference in 2014, conference leaders proposed expanding the scope of the conference beyond managing forest vegetation to include all topics related to forest establishment and early stand dynamics. Conference attendees agreed to change the name of IUFRO Unit 1.01 .04 at the 2014 meeting. This conference is the first to be held under this new title and broader theme 1.01.04-Forest Establishment and Early Growth Dynamics (Coordinator: Robert G. Wagner, United States; Deputy: Nicholas McCarthy, Ireland). This conference also was organized as a joint meeting with IUFRO 2.01.15-Whole Plant Physiology (Coordinator: Douglass F. Jacobs, United States; Deputies: Barbara J. Hawkins, Canada and Pedro Villar-Salvador, Spain).

\section{Overview of papers in special issue}

The papers submitted and accepted for publication by New Forests from the 2017 international conference on Forest Regeneration in Changing Environments are presented in this special issue. The issue includes 10 papers covering a variety of topics affecting regenerating forests from northern Europe to the western, central, and southern regions of the USA to northern Chile. A brief summary of the research findings in these papers is presented below:

\section{Northern Europe}

Results from three studies are presented from Sweden focused on improving survival of a native conifer, testing adaptation of Douglas-fir to northern climates, and poplar performance for rapid wood fiber production. Wallertz et al. (2018) investigated how the choice of site preparation method in southern Sweden can influence the quality of planting spots and the relation to the subsequent growth and survival of newly planted Norway spruce (Picea abies) seedlings, as well as damage from the pine weevil (Hylobius abietis). In areas where the pine weevil is a major threat, increasing the area of mineral soil around planted seedlings was the most important factor in reducing weevil damage. All three tested site preparation methods reduced pine weevil damage relative to no site preparation, and the proportion of planting spots with mineral soil was inversely related to the rate of mortality caused by the weevil.

Malmqvist et al. (2018) examined the early growth, survival, and damage from late spring frost and winter desiccation in a provenance trial in southwest Sweden comparing four coastal and three interior provenances of Douglas-fir (Pseudotsuga menziesii var. menziesii and var. glauca) from British Columbia, Canada. Interior Douglas-fir had a higher 
survival than coastal varieties after six growing seasons but were more frequently damaged by late spring frost. All provenances were damaged by winter desiccation, but coastal provenances were more severely damaged.

Hjelm et al. (2018) found that the survival and growth of poplars (Populus spp.) were improved by mulching for 5 years after planting, and that in most cases, long cuttings outperformed short cuttings and rooted plants. Clonal differences were found among $12 \mathrm{com}$ mercially available clones, indicating the importance of using plant material adapted to site conditions. All sites were heavily affected by ungulate browsing during the experiment, thus fencing is likely required to successfully grow Populus in this region.

In an effort to identify effective herbicides to control Gaultheria shallon (an invasive competitive shrub that interferes with native forest regeneration) in the southern UK, Willoughby et al. (2018) examined efficacy of picloram, triclopyr, and glyphosate herbicides. A single application of picloram between spring and midsummer killed all treated plants within two growing seasons. Triclopyr applied when flower buds were swelling or flushed (but vegetative buds were largely dormant) also was effective. If triclopyr or picloram cannot be used, glyphosate was found to provide some control, but follow up treatments would likely be required.

\section{Western, midwestern, and southern USA}

Drought is an annual factor influencing forest productivity across much of the western US. Research by Gonzalez-Benecke and Dinger (2018) in western Oregon, USA examined the use of a water stress integral (WSI) to evaluate stand productivity in young Douglas-fir plantations. They found a strong relationship between whole season WSI and Douglasfir volume growth during the initial two seasons after planting. The authors also found a strong relationship between mid-August soil volumetric water content and whole season WSI. Results from this study indicated that conserving soil moisture until early-August by controlling competing vegetation around seedlings can be critical to maximizing early stand growth. A single evaluation of soil volumetric water content during early August can be used as a predictor of WSI and early stand growth.

In the rain shadow of the Cascade Mountains in northeastern Oregon, Cole et al. (2018) examined the 8-year performance of interior bareroot Douglas-fir seedlings, and bareroot and plug western larch (Larix occidentalis Nutt.) following various herbicide sitepreparation treatments. Although some herbicide treatments increased seedling survival, the results were not consistent among sites. Douglas-fir had higher survival than larch, but seedling size was highly variable among sites and treatments. Size for all stock types was negatively correlated with vegetative cover and positively correlated with soil moisture in the first-year following treatment. Macro- and micro-climatic conditions, including topography and soil depth, were likely contributors to differences in seedling survival and growth.

Berrill et al. (2018) studied the relation between understory light, varying overstory tree retention, and growth of coast redwood (Sequoia sempervirens) and tanoak (Notholithocarpus densiflorus) stump sprouts following partial harvesting in 80- to 100-year-old mixedspecies stands in northern California. Post-harvest stand density index and basal area were found to be useful predictors of understory light conditions after harvest, with understory light levels not differing among harvest treatments. Redwood stump sprouts generally grew faster than dominant tanoak, with sprout height growth increasing with stump size. 
American chestnut (Castanea dentata) was once a dominant hardwood species across much of the eastern US, but was decimated by the introduced chestnut blight (Cryphonectria parasitica) pathogen. In the midwestern USA, Lesko and Jacobs (2018) found that hybrid American chestnut and northern red oak (Quercus rubra) seedlings were taller and had larger stem diameters after two growing seasons when underplanted in clearcut and shelterwood harvested stands dominated by eastern white pine (Pinus strobus) than when grown in an unharvested control or open field condition. Chestnut height and stem growth were three times that of oak after two growing seasons. In general, fertilization increased seedling growth more in the clearcut and open field than shelterwood and control for both tree species. Results from this study suggest that older pine plantations may serve as target sites for restoration of these important hardwood species.

Sayer et al. (2018) studied the influence of spring or fall prescribed fires on the viability of longleaf pine (Pinus palustris) ecosystems in the southeastern USA. They identified two means of foliage re-establishment in the growing season after prescribed fire that were independent of season of fire application. New foliage growth after spring or fall fires was correlated with un-scorched foliage biomass and the presence of lateral branches. They demonstrated a positive relationship between the timely recovery of foliage in young longleaf pines after fire and residual foliage, lateral branches, and stored starch.

\section{Northern Chile}

Bown et al. (2018) investigated the effects of copper mining on forest plantations of native species under conditions of strong water limitations in northern Chile. Mining companies in Chile establish and maintain forest plantations with native species using irrigation in areas away from the direct mining impact. Unfortunately, the survival and development success of these plantations has been mixed. The purpose of this study was to assess water consumption and balance for eight plant species, seven water-conservative (mostly sclerophyllous) and one water-demanding hygrophyte (Drimys winteri), to potentially reduce the amount of required irrigation needed. Tree growth and soil volumetric water content were monitored for the eight tree species over 2 years. A water balance model was used to prescribe best irrigation practices. Results indicated that irrigation can be reduced by $25 \%$ for xerophyllous/sclerophyllous trees and by $33 \%-67 \%$ for the hygrophytic species, especially when using mulches. Planting holes were found to act as water reservoirs with volumetric water content increasing with soil depth and was also less variable than in the upper soil layers.

\section{Conclusion}

With the conclusion of the symposium, we renewed our commitment to maintain our multidisciplinary IUFRO working group, Forest Establishment and Early Growth Dynamics, and continue to meet periodically to collectively address forest regeneration issues. We agreed that the next symposium would be held during 2020 in Ireland. 


\section{References}

Berrill JP, Schneider K, Dagley CM, Webb LA (2018) Understory light predicts stump sprout growth in mixed multiaged stands in North Coastal California. New For. https://doi.org/10.1007/s1105 6-018-9636-6

Bown HE, Fuentes JP, Martinez AM (2018) Assessing water use and soil water balance of planted native tree species under strong water limitations in Northern Chile. New For. https://doi.org/10.1007/s1105 6-018-9689-6

Cole E, Lindsay A, Newton M, Bailey J (2018) Eight-year performance of bareroot Douglas-fir and bareroot and plug western larch seedlings following herbicide applications, Northeast Oregon, USA. New For 55:25-27. https://doi.org/10.1007/s11056-018-9653-5

Gonzalez-Benecke CA, Dinger EJ (2018) Use of water stress integral to evaluate relationships between soil moisture, plant water stress and stand productivity in young Douglas-fir trees. New For. https://doi. org/10.1007/s11056-018-9657-1

Hjelm K, McCarthy R, Rytter L (2018) Establishment strategies for poplars, including mulch and plant types, on agricultural land in Sweden. New For. https://doi.org/10.1007/s11056-018-9652-6

Lesko J, Jacobs DF (2018) Conversion of conifer plantations to native hardwoods: influences of overstory and fertilization on artificial regeneration. New For. https://doi.org/10.1007/s11056-018-9683-z

Malmqvist C, Wallertz K, Johansson U (2018) Survival, early growth and impact of damage by late spring frost and winter desiccation on Douglas-fir seedlings in southern Sweden. New For. https://doi. org/10.1007/s11056-018-9635-7

Sayer MAS, Tyree MC, Dillaway DN, Rudd B (2018) Foliage re-establishment of Pinus palustris Mill. saplings after spring or fall prescribed fire. New For. https://doi.org/10.1007/s11056-018-9674-0

Wagner RG, Gonzalez-Benecke CA, Jacobs DF, Nelson AS (2017) Proceedings for forest regeneration in changing environments, July 11-13th, 2017, Corvallis, OR, USA. Meetings of IUFRO unit 1.01.04forest establishment and early growth dynamics and IUFRO 2.01.15-whole plant physiology. Unpublished Proceedings of Oregon State University's College of Forestry, Purdue University's Department of Forestry and Natural Resources, and the University of Idaho's Department of Forest, Rangeland and Fire Sciences

Wallertz K, Björklund N, Hjelm K, Peterson M, Sundblad LG (2018) Comparison of different site preparation techniques: quality of planting spots, seedling growth and pine weevil damage. New For. https:// doi.org/10.1007/s11056-018-9634-8

Willoughby IH, Forster J, Stokes VJ (2018) Gaultheria shallon can be controlled by the herbicides picloram, triclopyr or glyphosate if they are applied at the correct time of year. New For. https://doi.org/10.1007/ s11056-017-9615-3 